\title{
PENDIDIKAN AGAMA ISLAM DAN PENDIDIKAN ISLAM TINJAUAN EPISTEMOLOGI, ISI, DAN MATERI
}

\author{
Mahmudi 1) * \\ ${ }_{1}^{1}$ Program Studi Sistem Informasi, \\ Universitas Nahdlatul Ulama Lampung \\ *E-mail: mahmudi.m.pd.i@gmail.com
}

\begin{abstract}
This paper presents two terms which have differences, namely Islamic religious education and Islamic education. To see these two terms, the author reviews them from two interrelated aspects, namely the epistemological aspect as the theory of knowledge and aspects of content or material which is one of the important points in understanding the curriculum. Meanwhile in terms of epistemology, Religious Education is more inclined to apply in educating in the context of Islam. While Islamic education speaks at the source level, in theory, the principle recorded is the forerunner of the Islamic Religious Education material itself. As for content or material, basically between Islamic Education with Islamic education as in an epistemological view, there is no difference which means that the terms contained in Islamic Education include aqidah, worship, and morals which are explained in terms of introduction to Allah SWT, potential, human functions, and morals.
\end{abstract}

Keywords: Education, Islamic Education, Epistemology

\begin{abstract}
Abstrak
Tulisan ini menyajikan dua istilah yang sementara memiliki perbedaan, yaitu pendidikan agama Islam dan pendidikan Islam. Untuk melihat kedua istilah tersebut, penulis mengulasnya dari dua aspek yang saling terkait, yaitu aspek epistemologis sebagai teori pengetahuan dan aspek isi atau materi yang merupakan salah satu poin penting dalam memahami kurikulum. Sementara itu dalam hal epistemologi, Pendidikan Agama lebih condong ke penerapan dalam mendidik dalam konteks Islam. Sementara pendidikan Islam berbicara di tingkat sumber, secara teori, prinsip yang dicatat menjadi cikal bakal materi Pendidikan Agama Islam itu sendiri. Adapun konten atau materi, pada dasarnya antara Pendidikan Agama Islam dengan pendidikan Islam seperti dalam pandangan epistemologis, tidak ada perbedaan yang berarti istilah yang terkandung dalam Pendidikan Islam meliputi akidah, ibadah, dan akhlak yang dijelaskan dalam hal pengantar kepada Allah SWT. , potensi, fungsi manusia, dan moral.
\end{abstract}

Kata Kunci: Pendidikan, Pendidikan Islam, Epistemologi

\section{PENDAHULUAN}

Term epistemologi merupakan bagian yang tak terpisah dari pembahasan filsafat. Darinya sumber ilmu, dengan kata lain kemunculan suatu ilmu bermula dari teori pengetahuan atau yang disebut epistemologi. Apabila teori pengetahuan dihubungkan dengan pendidikan agama Islam, maka yang menjadi fokus pembicaraan adalah pengajaran agama Islam apa saja yang terkait dengan pendidikan? Bila pertanyaan tersebut yang menjadi fokus pembicaraan, maka jawabannya adalah semua aspek yang diajarkan dalam Islam adalah bernilai pendidikan tanpa terkecuali. Semua aspek yang 
dimaksud terangkum dalam term akidah, ibadah, dan akhlak. Ketiga term ini melingkupi pembahasan yang sangat luas, namun tetap bermuara pada pembahasan mengenai pengenalan kepada Allah SWT., potensi dan fungsi manusia, dan akhlak.

Bagian yang tidak terpisahkan dalam masalah-masalah pendidikan adalah guru, anak didik, kurikulum, metode, evaluasi dan tujuan. Salah satu bagian yang patut mendapat perhatian adalah masalah kurikulum. Kurikulum dalam definisi Undangundang Sistem Pendidikan Nasional nomor 2 tahun 2003 adalah seperangkat rencana dan pengaturan mengenai tujuan, isi, dan bahan pelajaran serta cara apa digunakan sebagai pedoman penyelenggaraan kegiatan pembelajaran untuk mencapai tujuan pendidikan tertentu. Menurut Muhaimin, dari definisi tersebut ada tiga komponen yang termuat dalam kurikulum, yaitu tujuan, isi, dan bahan pelajaran, serta cara pembelajaran, baik berupa strategi pembelajaran maupun evaluasinya.

Dari penjelasan di atas akan penting bahwa pendidikan memiliki hubungan yang erat dengan pendidikan Islam dan apa yang diinginkan oleh pendidikan secara nasional yang tersirat dalam definisi kurikulum dalam sistem pendidikan nasional. Di sini penulis melalui tulisan ini melihat kembali pada pemikiran untuk tujuan pendidikan agama Islam (PAI) dan pendidikan Islam dalam hal aspek dan konten epistemologis (materi).

\section{METODE}

Jenis penelitian ini adalah metode Penelitian Perpustakaan, Penelitian ini ditulis berdasarkan hasil studi dari berbagai bahan pustaka yang relevan, baik dalam bentuk buku, jurnal, artikel dan lain-lain yang terkait dengan fokus masalah di atas. Data yang dikumpulkan dalam penelitian ini adalah data kualitatif yang bersifat tekstual dalam bentuk pandangan dan pemikiran yang ada dalam bahan pustaka yang dimaksud.

Sejalan dengan metode yang digunakan, teknik pengumpulan data yang tepat untuk digunakan dalam penelitian ini adalah teknik dokumenter: yaitu, data dikumpulkan melalui dokumen yang dimaksudkan sebagai bahan pustaka. Data yang dikumpulkan dalam penelitian ini kemudian dianalisis menggunakan analisis isi. Dengan teknik ini, data kualitatif tekstual diurutkan (disortir), dilakukan katagorisasi (pengelompokan) antara data yang serupa, dan kemudian dianalisis isinya secara kritis untuk mendapatkan formulasi yang konkret. Selanjutnya, formulasi dijelaskan secara mendalam. 


\section{PEMBAHASAN}

Definisi Pendidikan dan Pendidikan Islam Ajaran pertama dalam Islam adalah ketika Jibril datang menemui Nabi Muhammad. yang ada di gua Hira. Dalam pengajarannya Jibril bertanya kepada Nabi. membaca dan mengikuti apa yang dibacakan kepadanya. Surah al-Alaq ayat 1 sampai 5 adalah bukti bahwa kemunculan Islam ditandai dengan pengajaran dan pendidikan sebagai fondasi utama setelah iman, Islam dan ihsan.

Yaitu terdapat pada makna ayat Alquran: "Bacalah dengan (menyebut) nama Tuhanmu Yang menciptakan. Dia telah menciptakan manusia dari segumpal darah. Bacalah, dan Tuhanmulah Yang Paling Pemurah. Yang mengajar (manusia) dengan perantaraan kalam. Dia mengajarkan kepada manusia yang tidak diketahuinya."

Dari ayat-ayat Al-Qur'an di atas setidaknya ada empat poin, yaitu pertama, manusia sebagai subjek dalam membaca, memperhatikan, merenungkan, meneliti dengan prinsip niat baik yang ditandai dengan menyebutkan nama Tuhan. Kedua, objek yang dibaca, diperhatikan, dan direnungkan, yaitu materi dan proses penciptaan menjadi manusia yang sempurna. Ketiga, media dalam melakukan aktivitas membaca dan lainnya. Dan keempat, motivasi dan potensi yang dimiliki oleh manusia,"rasa ingin tahu".

Pengertian ayat di atas berarti jika dikaitkan dengan faktor-faktor yang berkaitan dengan proses pendidikan dalam arti mikro, yaitu: pendidik, siswa, dan alat pendidikan, baik materiil maupun nonbahan (Arifin, 2003: 8). Pendidikan adalah proses berkesinambungan dalam kehidupan manusia mulai dari usia 0 (nol) hingga manusia sempurna (dewasa). Bahkan Muhammad Abd. Alim mengatakan bahwa pendidikan dimulai dari ketika memilih perempuan sebagai istri.

Pendapat ini didasarkan pada hadits Nabi, yaitu "Takhayyaru li nutfikum fa innal „Irqa dassas”. Artinya: "pilihlah olehmu tempat benih kamu, sebab akhlak ayah itu menurun kepada anak" (Muhammad,1992:44-45). karena Islam sangat memperhatikan pendidikan, terutama proses tumbuh kembang anak sejak awal pemilihan benih hingga membentuk individu individu dalam kehidupan. Dan mereka yang berperan dalam membina kepribadian dan pendidikan anak-anak adalah orang tua, masyarakat dan sekolah.

Pendidikan sebagai upaya membina dan mengembangkan pribadi manusia; aspek spiritual dan fisik, juga harus berlangsung secara bertahap. Karena tidak ada 
ciptaan Tuhan yang secara langsung diciptakan dengan sempurna tanpa melalui proses. (Arifin, 2003: 12). Kematangan dan kesempurnaan yang diharapkan bertitik tolak pada pengoptimalan kemampuannya dan potensinya. Tujuan yang diharapkan tersebut mencakup dimensi vertikal sebagai hamba Tuhan; dan dimensi horisontal sebagai makhluk individual dan sosial. Hal ini dimaknai bahwa tujuan pendidikan dalam pengoptimalan kemampuan atau potensi manusia terdapat keseimbangan dan keserasian hidup dalam berbagai dimensi.

Demikian pula yang diharapkan oleh pendidikan agama Islam (Muhaimin. 2007: 6) berpendapat bahwa pendidikan agama Islam bermakna upaya mendidikkan agama Islam atau ajaran Islam dan nilai-nilainya agar menjadi pandangan dan sikap hidup seseorang. Dari aktivitas mendidikkan agama Islam itu bertujuan untuk membantu seseorang atau sekelompok anak didik dalam menanamkan dan /atau menumbuhkembangkan ajaran Islam dan nilai-nilainya untuk dijadikan sebagai pandangan hidupnya.

Sementara itu Harun Nasution yang dikutip oleh Syahidin mengartikan tujuan Pendidikan Agama Islam (secara khusus di sekolah umum) adalah untuk membentuk manusia takwa, yaitu manusia yang patuh kepada Allah dalam menjalankan ibadah dengan menekankan pembinaan kepribadian muslim, yakni pembinaan akhlakul karimah, meski mata pelajaran agama tidak diganti mata pelajaran akhlak dan etika (Syahidin, 2005: 20).

Dalam term yang serupa (menurut penulis) dengan pendidikan agama Islam adalah Pendidikan Islam. Al-Syaibani mengartikannya sebagai "usaha pendidikan untuk mencapainya, baik pada tingkah laku individu dan pada kehidupan pribadinya atau pada kehidupan masyarakat dan pada kehidupan alam sekitar .....pada proses kependidikan..."(Syaibany,1979: 399). Sedangkan Al- Nahlawi memberikan pengertian pendidikan Islam adalah "sebagai pengaturan pribadi dan masyarakat sehingga dapat memeluk Islam secara logis dan sesuai secara keseluruhan baik dalam kehidupan individu maupun masyarakat (kolektif)"(Abdurrahman, 1979: 20).

Hal yang senada juga disampaikan Muhammad Fadhil al-Jamaly; mendefinisikan pendidikan Islam sebagai upaya mengembangkan, mendorong serta mengajak peserta didik hidup lebih dinamis dengan berdasarkan nilai-nilai yang tinggi dan kehidupan yang mulia. Dengan proses tersebut, diharapkan akan terbentuk pribadi peserta didik 
yang lebih sempurna, baik yang berkaitan dengan potensi akal, perasaan, maupun perbuatannya (Rasyidin,1995: 31-32).

Ahmad D. Marimba; mengemukakan bahwa pendidikan Islam adalah bimbingan atau pimpinan secara sadar oleh pendidik terhadap perkembangan jasmani dan rohani peserta didik menuju terbentuknya kepribadiannya yang utama (insan kamil). Juga Ahmad Tafsir; mendefinisikan pendidikan Islam adalah bimbingan yang diberikan oleh seseorang kepada seseorang agar ia berkembang secara maksimal sesuai dengan ajaran Islam (Ahmad, 1994: 32).

Dari definisi pendidikan agama Islam dan beberapa definisi pendidikan Islam di atas, terdapat kemiripan makna yaitu keduanya sama-sama mengandung arti pertama, adanya usaha dan proses penanaman sesuatu (pendidikan) secara kuntinue. Kedua, adanya hubungan timbal balik antara orang pertama (orang dewasa, guru, pendidik) kepada orang kedua, yaitu peserta dan anak didik. dan ketiga adalah akhlakul karimah sebagai tujuan akhir. Namun tidak kalah pentingnya dari aspek epistemologi bahwa pembinaan dan pengoptimalan potensi; penanaman nilai-nilai Islam dalam jiwa, rasa, dan pikir; serta keserasian dan keseimbangan.

Muhaimin memberikan karakteristik Pendidikan Agama Islam yang berbeda dengan yang lain, yaitu:

1. Pendidikan Agama Islam berusaha menjaga akidah peserta didik agar tetap kokoh dalam situasi dan kondisi apapun.

2. Pendidikan Agama Islam berusaha menjaga dan memelihara ajaran dan nilai-nilai yang tertuang dan yang terkandung dalam Alquran dan al-sunnah serta otentisitas keduanya sebagai sumber utama ajaran Islam

3. Pendidikan Agama Islam menonjolkan kesatuan iman, ilmu, dan amal dalam kehidupan keseharian.

4. Pendidikan Agama Islam berusaha membentuk dan mengembangkan kesalehan individu dan sekaligus kesalehan sosial.

5. Pendidikan Agama Islam menjadi landasan moral dan etika dalam pengembangan iptek dan budaya serta aspek-aspek kehidupan lainnya.

6. Substansi Pendidikan Agama Islam mengandung entitas-entitas yang bersifat rasional dan supra rasional.

7. Pendidikan Agama Islam berusaha menggali, mengembangkan dan mengambil ibrah dari sejarah dan kebudayaan (peradaban) Islam. 
Dalam beberapa hal, Pendidikan Agama Islam mengandung pemahaman dan penafsiran yang beragam, sehingga memerlukan sikap terbuka dan toleran atau semangat ukhuwah Islamiyah (Muhaimin, 2007: 123).

Dari uraian diatas penulis mengambil kesimpulan Pendidikan Agama Islam yang sesuai dengan tuntunan Nabi Muhmmad SAW sebagai mana tercantum dalam AlQur'an dan Hadist serta pendidikan Islam yang berkaitan dengan pengamalan dari nilai-nilai Agama Islam yaitu rukun iman dan rukun islam secara keseluruhan.

Epistemologi; Hubungan dengan Pendidikan Islam dan Pendidikan Islam Karena filsafat dikenal dalam kehidupan manusia, menurut asal kata "filsafat" itu sendiri, yaitu philos yang berarti "cinta" dan sophos yang berarti "kebenaran", maka sejak itu pencarian manusia akan kebenaran mulai dilakukan, pengetahuan manusia tentang alampun mulai berkembang, dari pengetahuan animisme dan dinamisme dengan berkembangnya berbagai mitos tentang para dewa dengan berbagai kekuatan gaib sehingga manusia kemudian mencoba mengartikan dunia ini terlepas dari belenggu mitos.

Manusia tidak lagi menatap kehidupan ini dari balik dupa harum dan asap dupa. Filsafat, cenderung diidentifikasi dengan menjawab berbagai pertanyaan tentang berbagai aspek kehidupan manusia. Pertanyaan-pertanyaan ini termasuk bagaimana kita memperoleh pengetahuan untuk pertanyaan tentang yang benar, yang baik, yang indah, sifat dari segala sesuatu, dan sebagainya. DW. Hamlyn dalam bukunya, History of Epistemology yang dikutip oleh Amsal Bakhtiar, epistemologi atau teori pengetahuan adalah cabang filsafat yang berhubungan dengan sifat dan ruang lingkup pengetahuan, prasuposisi, serta fondasi dan tanggung jawabnya untuk pernyataan tentang pengetahuan yang dimiliki (Bakhtiar, 1994: 148).

Muthahhari menyebutkan bahwa ada empat sumber epistemologi, yakni: alam, rasio, hati dan sejarah (Suharto, 1999: 31). Dalam bahasa yang berbeda Noeng Muhadjir mengatakan bahwa dalam pengenalan terhadap beragam objek bisa diserap lewat indera, akal rasio, akal budi, dan intuisi serta keimanan kita (Muhadjir, 1998: 56). Jadi, dari sumber epistemologi dalam prosesnya akan melahirkan sains yang merupakan keharusan dalam membangun peradaban. Jika epistimologi dikaitkan dengan pendidikan Islam, maka objek pembahasannya adalah seluk-beluk pengetahuan Islam, sifat agama Islam, sumber agama Islam, metode dan metode pendidikan Islam, serta evaluasi dan tujuan pendidikan Islam. 
Sementara itu menurut Mujamil Qomar, jika epistimologi dikaitkan dengan pendidikan Islam, pembahasannya meliputi; diskusi yang berkaitan dengan seluk beluk pengetahuan pendidikan Islam mulai dari sifat pendidikan Islam, asal usul pendidikan Islam, sumber pendidikan Islam, metode membangun pendidikan Islam, unsur pendidikan Islam, target pendidikan Islam, sasaran pendidikan Islam, berbagai jenis pendidikan Islam dan sebagainya (Qomar, 2005: 249).

Pendidikan dan Pendidikan Agama Islam; Ikhtisar Konten dan Materi, Konten atau materi tidak dapat dipisahkan dari konsep kurikulum. Muhaimin melihat makna yang terkandung dalam definisi kurikulum dalam sistem pendidikan nasional adalah bahwa ada dua pemahaman berbeda dalam melihat makna kurikulum, pertama, kurikulum yang menekankan pada aspek konten, dimana masyarakat dianggap statis, pendidik. Kedua, kurikulum yang menekankan proses dan pengalaman yang tentunya melibatkan siswa. Sehingga tidak ada asumsi bahwa tidak ada kurikulum standar, hanya ada kurikulum minimal dalam implementasinya dikembangkan bersama siswa.

Menurut Ashan, yang dikutip oleh E. Mulyasa, menyatakan: Tiga hal perlu dipertimbangkan dalam pengembangan kurikulum berbasis kompetensi, yaitu penentuan kompetensi yang ingin dicapai, pengembangan strategi untuk mencapai kompetensi, dan evaluasi. Kompetensi yang ingin dicapai adalah pernyataan yang ingin didapatkan siswa, menggambarkan hasil belajar pada aspek pengetahuan, keterampilan, nilai, dan sikap. Strategi untuk mencapai kompetensi adalah upaya untuk membantu siswa menguasai kompetensi yang ditetapkan, misalnya: membaca, menulis, mendengarkan, menciptakan, dan mengamati, hingga kompetensi terbentuk. Sedangkan evaluasi adalah kegiatan penilaian terhadap pencapaian kompetensi untuk setiap siswa (Mulyasa, 2004: 41-42).

Inti dari pembahasan kurikulum di atas adalah tentang pengetahuan yang didapat, penerapan pengetahuan itu dan aspek nilai. Semua aspek ini jika dilihat dari pandangan pendidikan agama Islam saling mendukung dan tidak bertentangan di mana kurikulum pendidikan nasional bertujuan untuk menumbuhkan iman dan pengabdian kepada Allah SWT, menumbuhkan penalaran yang baik (mau belajar, ingin tahu, kreatif dan bertanggung jawab) Dalam pendidikan agama Islam ada tiga mata pelajaran utama, yaitu aqidah, ibadah dan moral. Sedangkan dalam bahasa pendidikan Islam, ketiga istilah tersebut dijelaskan dalam hal pengantar kepada Allah SWT, potensi dan fungsi manusia, dan akhlak. 
Berikut ini adalah penjelasan dari istilah dalam pendidikan Islam yang mirip dengan pendidikan agama Islam, sebagai berikut:

1. Pengenalan terhadap Allah SWT

Allah SWT. sebagai pencipta alam semesta. Pencipta yang tidak terlihat oleh mata telanjang. Namun, manusia telah diberkati dengan "rasa" yang mampu membimbing manusia untuk mencari Pencipta Yang Maha Kuasa (rasa iman). Ini bisa diamati, salah satunya adalah pertumbuhan anak. Artinya, sejak dalam kandungan, janin sudah mengenal sumber kehidupan dalam aspek biologisnya, dalam hal ini adalah sang ibu. Dia janin tidak bisa lepas dari lengan dan belaian ibu. Ini berlanjut hingga ia dilahirkan (bayi) dapat mendengar dan melihat dilahirkan ke dunia sebagai hamba Tuhan dengan tugas utamanya sesuai dengan tuntunan AlQur'an, yaitu sebagai khalifah di bumi.

Demikian juga hubungannya dengan Pencipta Yang Maha Kuasa, yang dalam istilah Islam adalah 'kecenderungan agama' atau fitrah. Al-Syaibany mengatakan bahwa perasaan religius ini adalah naluri yang disatukan ketika manusia dilahirkan. Pada saat yang sama ini juga membayangkan kebutuhan dasar manusia untuk mencapai kedamaian dan kebahagiaan (Syaibany,1979: 121). Nilai-nilai inilah yang dididikan kepada anak didik sebagai materi Pendidikan agama Islam kita harus pahami bersama agar tujuan dari pendidikan ini bisa mengenai sasaran yang tepat dan bisa di terapan dalam kehidupan sehari-hari. Supaya terbina rasa ketakwaan kepada Allah yang kokoh dan selalu terpatri dalam keseharian sebagai mana yang di contohkan oleh Nabi Muhmmad SAW.

\section{Potensi dan fungsi manusia}

Manusia diberkati dengan Tuhan dalam bentuk potensi yang diharapkan mampu melaksanakan misi suci sebagai khalifah Allah di bumi dan pada saat yang sama sebagai „abd Allah,, hamba Allah. Oleh karena itu, ia dilengkapi dengan pembentukan potensi seperti alasan, hati, rasa, dan nafsu (sumber daya manusia / SDM). Sebenarnya keempat potensi ini bila diberdayakan akan tercipta kekuatan yang "dahsyat" yang mampu mengemban amanah yang dibebankan kepadanya. Alam juga merupakan potensi bagi manusia yang bisa dimanfaatkan bagi kehidupan atau yang disebut dengan sumber daya alam (SDA) yang mana harus dikelola oleh manusia yang sesuasi dengan anturan Al-Qur'an, Hadits, ijma dan Qias agar tidak menimbulkan kerusakan di alam semesta ini.Sebenarnya, keempat potensi ini, jika 
diberdayakan, akan menciptakan kekuatan "kuat" yang mampu menjalankan mandat yang dibebankan padanya. Alam juga merupakan potensi bagi manusia yang dapat digunakan untuk kehidupan atau yang disebut sumber daya alam (SDA) yang harus dikelola oleh manusia yang sesuai dengan distribusi Alquran, Hadits, ijma dan Qias agar tidak menyebabkan kerusakan di alam semesta ini.

Epistemologi Islam bersumber dari pedoman hidup muslim, berupa kalam ilahi (Alquran) yang selalu memberikan pancaran hidayah Allah bagi siapa saja yang membaca, memahami dan menggalinya. Surat al- Alaq ayat 1-5 merupakan bukti bahwa Alquran merupakan kitab yang menaruh perhatian terhadap pendidikan , tuntunan dan ajaran. Demikian pula dengan lafaz-lafaz dan ungkapan-ungkapan yang digunakan agar manusia berfikir, menggunakan akal untuk mendapatkan pengetahuan yang benar, seperti kata-kata nazara (memperhatikan), tadabbara (merenungkan), tafakkur (memikirkan), faqiha (mengerti), tazakkara (mempelajari), fahima (memahami), dan „aqala (mempergunakan akal) (Asmaran, 2005: 325-326).

Juga yang menjadi sumber pengetahuan bagi epistemologi Islam adalah hadis. Hadis diakui memberikan perhatian yang amat besar terhadap pendidikan. Nabi Muhammad Saw. mencanangkan program pendidikan seumur hidup (long life education), seperti uthlub al-,,ilm min al-mahd ila al-lahd. Selanjutnya pada hadis yang lain menegaskan kewajiban menuntut ilmu bagi muslim laki-laki dan muslim perempuan, seperti thalab al-,,ilm faridhah „ala kulli muslim wa mulimah (Abuddin, 1997: 12).

Sumber pengetahuan lain adalah pikiran, perasaan dan kesadaran. Dengan ketiga potensi ini, manusia diharapkan dapat menggunakannya secara optimal untuk menemukan kebenaran pamungkas dan mendapatkan pengetahuan yang bermanfaat untuk kelangsungan hidupnya. Karena sains berfungsi sebagai:

a. tahu yang sebenarnya,

b. jelaskan ajarannya/aqidah Islamiyah, menguasai alam,

c. meningkatkan budaya dan peradaban Islam (Ihsan, 1998: 36).

Secara lebih rinci keistimewaan-keistimewaan yang dianugerahkan Allah kepada manusia antara lain adalah kemampuan berfikir untuk memahami alam semesta (Q.S, Ar Ra'ad/13:3) dan dirinya sendiri (Q.S, Ar Rum/30:20-21), akal untuk memahami tanda-tanda keagungan-Nya (Q.S. Al- Hajj/22: 46), nafsu yang paling 
rendah (Q.S, Yusuf/12:53) sampai yang tertinggi kalbu untuk mendapat cahaya tertinggi (Q.S, Al Fajr/89:27-30, dan ruh yang kepadanya Allah Swt mengambil kesaksian manusia (Q.S, Al A'raf/7:172-174) (Rasyidin,1995:17). Islam sangat mendorong orang untuk mencari ilmu. Bahkan dalam berbagai tradisi, dikatakan bahwa proses mencari pengetahuan adalah bagian dari melaksanakan ibadah wajib bagi setiap wanita Muslim dan Muslim. Jadi pikiran, perasaan dan kesadaran sebagai media bagi manusia untuk memperoleh pengetahuan yang benar. Sehingga iman, pengetahuan dan amal terlihat baik dalam kesalehan individu dan kesalehan sosial dan dapat menciptakan kesejukan dalam bangsa dan negara sebagai apa yang kita harapkan bersama.

3. Akhlak

Akhlak merupakan bagian penting dalam kehidupan muslim. Sebab misi Nabi dalam dakwahnya adalah memperbaiki akhlak umat manusia, sebagai mana sabdanya: "Innama buitstu li utammima makarim al-akhlak", bahwasanya aku diutus untuk menyempurnakan akhlak. Misi dakwah Nabi Muhammad SAW tersebut sesuai dengan tujuan pendidikan Islam, yaitu mempertinggi nilai-nilai akhlak hingga mencapai tingkat akhlak mulia. Faktor kemulian akhlak dalam pendidikan Islam dinilai sebagai faktor kunci dalam menentukan keberhasilan pendidikan, yang menurut pandangan Islam berfungsi menyiapkan manusia-manusia yang mampu menata kehidupan yang sejahtera di dunia dan kehidupan di akhirat (Ihsan, 1998: 38). Dari makna yang terkandung dalam nilai-nilai moral ini, siswa dalam mengembangkan ilmu pengetahuan dan teknologi serta budaya dan aspek kehidupan lainnya tidak dapat dipisahkan dari landasan moral dan etika.

4. Bayani, 'Irfani dan Burhani

Pengertian Bayani Secara etimologi, Bayan berarti penjelasan (eksplanasi). AlJabiri berdasarkan beberapa makna yang diberikan kamus lisan al Arab mengartikan sebagai al fashl wa infishal (memisahkan dan terpisah) dalam kaitannya dengan metodologi dan al dhuhur wa al idhar (jelas dan penjelasan) berkaitan dengan visi dari metode bayani (al-Jabiri, 2000: 60). Sementara itu, secara terminology bayan mempunyai dua arti (1) sebagai aturan penafsiran wacana, (2) sebagai syarat-syarat memproduksi wacana. Berbeda dengan makna etimologi yang telah ada sejak awal peradaban Islam, makna etimologis ini baru lahir belakangan, yakni pada masa kodifikasi (tadwin). Bayani adalah metode pemikiran khas Arab 
yang menekankan otoritas teks (nash), secara langsung atau tidak langsung. Langsung berarti memahami teks sebagai pengetahuan yang sudah selesai dan segera menerapkannya tanpa perlu berpikir; secara tidak langsung berarti memahami teks sebagai pengetahuan mentah sehingga perlu interpretasi dan penalaran. Namun, ini tidak berarti bahwa alasan atau rasio dapat bebas menentukan makna dan tujuan, tetapi tetap harus bergantung pada teks.

Perkembangan Bayani Pada masa Syafi'i (767-820 M), bayani berarti nama yang mencakup makna-makna yang mengandung persoalan ushul/pokok dan yang berkembang hingga ke furu' atau cabang. Dari segi metodologi, Syafi'i membagi bayan dalam lima bagian dan tingkatan, yaitu: 1) Bayan yang tidak butuh penjelasan lanjut berkenaan dengan sesuatu yang telah dijelaskan Tuhan dalam al Qur'an sebagai ketentuan bagi makhlukNya, 2) Bayan yang beberapa bagiannya masih global sehingga butuh penjelasan sunnah, 3) Bayan yang keseluruhannya masih global sehingga butuh penjelasan sunnah, 4) Bayan sunnah sebagai uraian atas sesuatu yang tidak terdapat dalam al Qur'an, 5) Bayan Ijtihad yang dilakukan dengan Qiyas atas sesuatu yang tidak terdapat dalam al Qur'an maupun sunnah. Dari lima derajat bayan tersebut, Syafi'I kemudian menyatakan bahwa yang pokok ada tiga yaitu al Qur'an, sunnah dan qiyas, kemudian ditambah ijma (Soleh, 2003: 182).

Metode Bayani untuk mendapatkan pengetahuan, bayani menempuh dua jalan. Pertama berpegang pada redaksi teks dengan menggunakan kaidah bahasa Arab. Kedua, menggunakan metode qiyas (analog) dan inilah prinsip utama epistemologi bayani. Dalam kajian ushul fikih, qiyas diartikan memberikan keputusan hukum suatu masalah berdasarkan masalah lain yang telah ada kepastian hukumnya dalam teks, Karena adanya kesamaan illah. Ada beberapa hal yang harus dipenuhi dalam melakukan qiyas: 1) Adanya al-Ashl yakni nash suci yang memberikan hukum dan dipakai sebagai ukuran, 2) al-far yakni sesuatu yang tidak ada hukumnya dalam nash,3) hukum al-ashl yakni ketetapn hukum yang diberikan oleh ashl, 4) illah yakni keadaan tertentu yang dipakai sebagai dasar ketetapan hukum Ashl (Soleh, 2003: 188-189).

Menurut Jabiri, metode qiyas sebagai cara mendapatkan pengetahuan dalam epistemologi bayani digunakan dalam 3 aspek yaitu : 1) qiyas jali, dimana far mempunyai persaolan hukum yang kuat di banding ashl ,2) qiyas fi makna an nash dimana ashl dan far mempunyai derajat hokum yang sama, qiyas al-kahfi dimana 
illat ashl tidak diketahui secara jelas dan hanya menurut perkiraan mujtahid. Menurut Abd al jabar, seorang pemikir teologi muktazilah, metode qiyas bayani diatas tidak hanya untuk menggali pengetahuan dari teks tetapi juga bisa dikembangkan dan digunakan untuk mengungkapkan persoalan non fisik ( ghoib). Pengertian Irfani Irfan dari kata dasar bahasa Arab 'arafah semakna dengan makrifat berarti pengetahuan.

Tapi ia berbeda dengan ilmu. Irfan atau makrifat berkaitan dengan pengetahuan yang diperoleh secara langsung lewat pengalaman sedangkan ilmu menunjuk pada pengetahuan yang diperoleh lewat transformasi (naql) atau rasianalitas (aql). Karena itu, secara terminologis, irfan bisa diartikan sebagai pengungkapan atas pengetahuan yang diperoleh lewat penyinaran hakikat oleh Tuhan kepada hambaNya setelah adanya olah ruhani yang dilakukan atas dasar cinta (Nicholson, 1987: 68).

Perkembangan irfani secara umum dibagi dalam 5 fase. Pertama, fase pembibitan, Terjadi pada abad pertama hijriyah. Apa yang disebut baru ada dalam bentuk prilaku zuhud. Kedua, Fase kelahiran terjadi pada abad kedua hijriyah. Jika awalnya zuhud dilakukan atas dasar takut dan mengharap pahala, dalam periode ini, ditangan Robiah al adawiyah ( $801 \mathrm{M}$ ) zuhud dilakukan atasa dasar cinta pada Tuhan, bebas dari rasa takut atau harapan mendapat pahala. Ketiga, Fase pertumbuhan terjadi abad $3-4 \mathrm{H}$, Para tokoh sufisme mulai menaruh perhatian terhadap hal hal yang berkaitan dengan jiwa dan tingkah laku, sehingga sufisme menjadi ilmu moral keagamaan (akhlak).

Keempat, fase puncak terjadi pada abad ke- 5 H. Pada periode ini Irfan mencapai masa gemilang. Irfan menjadi jalan yang jelas karakternya untuk mencapai pengenalan serta kefanaan dalam tauhid dan kebahagiaan. Kelima, fase spesikasi terjadi abad ke-6 dan $7 \mathrm{H}$ berkat pengaruh al ghozali yang besar, Irfan menjadi semakin dikenal dan berkembang dalam masyarakat islami . Pada fase ini, secara epistemologi irfan telah terpecah dalam 2 aliran yaitu irfan sunni dan irfan teoristis. Keenam, fase kemunduran terjadi abad ke -8 sejak abad itu, irfan tidak mengalami perkembangan bahkan mengalami kemunduran.

Metode Irfani Pengetahuan irfan tidak didasarkan atas teks seperti bayani, tetapi pada kasyf, tersingkapnya rahasia-rahasia realitas oleh Tuhan. Karena itu, pengetahuan irfani tidak diperoleh berdasarkan analisa teks tetapi dengan olah 
ruhani, dimana dengan kesucian hati, diharapkan Tuhan akan melimpahkan pengetahuan langsung kepadanya. Masuk dalam pikiran, dikonsep kemudian dikemukakan kepada orang lain secara logis. Dengan demikian pengetahuan irfani setidaknya diperoleh melalui tiga tahapan, (1) persiapan, (2) penerimaan, (3) pengungkapan, dengan lisan atau tulisan (Soleh, 2003: 204).

Tahap pertama, persiapan. Untuk bisa menerima limpahan pengetahuan (kasyf), seseorang harus menempuh jenjang-jenjang kehidupan spiritual. Setidaknya, ada tujuh tahapan yang harus dijalani, mulai dari bawah menuju puncak (1) Taubat, (2) Wa r a ', menjauhkan diri dari segala sesuatu yang subhât, (3) Zuhud, tidak tamak dan tidak mengutamakan kehidupan dunia. (4) Faqir, mengosongkan seluruh fikiran dan harapan masa depan, dan tidak menghendaki apapun kecuali Tuhan swt, (5) Sabar, menerima segala bencana dengan laku sopan dan rela. (6)Tawakkal, percaya atas segala apa yang ditentukan-Nya. (7) Ridla, hilangnya rasa ketidaksenangan dalam hati sehingga yang tersisa hanya gembira dan sukacita.

Kedua, tahap penerimaan. Jika telah mencapai tingkat tertentu dalam sufisme, seseorang akan mendapatkan limpahan pengetahuan langsung dari Tuhan secara illuminatif. Pada tahap ini seseorang akan mendapatkan realitas kesadaran diri yang demikian mutlak (kasyf), sehingga dengan kesadaran itu ia mampu melihat realitas dirinya sendiri (musyâhadah) sebagai objek yang diketahui. Namun, realitas kesadaran dan realitas yang disadari tersebut, keduanya bukan sesuatu yang berbeda tetapi merupakan eksistensi yang sama, sehingga objek yang diketahui tidak lain adalah kesadaran yang mengetahui itu sendiri, begitu pula sebaliknya (ittihâd) yang dalam kajian Mehdi Yazdi disebut 'ilmu huduri' atau pengetahuan swaobjek (self-object-knowledge).

Ketiga, pengungkapan, yakni pengalaman mistik diinterpretasikan dan diungkapkan kepada orang lain, lewat ucapan atau tulisan. Namun, karena pengetahuan irfani bukan masuk tatanan konsepsi dan representasi tetapi terkait dengan kesatuan simpleks kehadiran Tuhan dalam diri dan kehadiran diri dalam Tuhan, sehingga tidak bisa dikomunikasikan, maka tidak semua pengalaman ini bisa diungkapkan.

Pengertian Burhani Dalam bahasa Arab al-burhan berarti argumen yang jelas. Bahasa latinnya berarti demonstration yang berarti al-isyarah (isyarat/tanda), alwashf (sifat), al-bayan (penjelasan), al-idzhar (menampakkam) (al-Jabiri, 2000: 
383). Secara umum ia berarti pembuktian untuk membenarkan sesuatu. Sebagai aktifitas kognitif, demonstrasi adalah inferensi rasional yaitu penggalian premispremis yang menghasilkan konklusi yang bernilai (al-Jabiri, 2000: 317). Sebagai lapangan kognitif, demonstrasi ini adalah dunia pengetahuan filsafat dan sains yang diderivasikan dari gerakan transliterasi buku-buku asing, khususnya karya Aristoteles ke dalam peradaban Arab.

Karena penerjemahan buku-buku itu dilatari oleh kehendak politik untuk mendukung akal retoris melawan serbuan tren akal gnostis, maka tidak heran kalau dalam praktiknya latar belakang ini mempunyai pengaruh yang dominan. Dan terjadilah hubungan yang sangat erat antara keduanya dalam tataran pemikiran teologi / filsafat.

Dari sini, kita bisa menganalisis proses akulturasi tren ini ke dalam peradaban Arab menurut perspektif epistemologisnya, menurut dua poros berikut. Pertama, dalam kaitannya dengan metodologi yaitu dengan menggunakan pendekatan pasangan epistemologisnya (al-lafdz/al-ma'na) yang sejajar dengan pasangan pertama dalam tren akal retoris dan kedua berkaitan secara khusus dengan pola pandang, yaitu dengan menggunakan pasangan epistemologis al-ashl/al-far' dan pasangan al-jauhar/al-'ardh dalam tren akal retoris (al-Jabiri, 2000: 318).

Perkembangan Burhani Prinsip burhani pertama kali dibangun oleh Aristoteles yang dikenal dengan istilah metode analitik (tahlili) yaitu suatu cara berfikir yang didasarkan atas proposisi tertentu. Pada masa Alexander Aprodisi murid serta komentator Aristoteles, digunakan istilah logika dan ketika masuk pada khasanah pemikiran Islam berganti nama menjadi Burhani.

Cara berpikir analitis Aristoteles memasuki pemikiran Islam untuk pertama kalinya melalui program penerjemahan buku-buku filsafat yang secara intensif dilakukan pada masa pemerintahan Al-Ma'mun. Sarjana pertama yang memperkenalkan dan menggunakan metode Burhani adalah al Khindi. Namun, karena dominasi masyarakat Bayani dan kurangnya referensi, metode burhani tidak begitu bergema. Metode Burhani ini semakin berkembang dalam sistem pemikiran Islam Arab setelah masa al-Rozi. Metode Burhani akhirnya mendapatkan tempatnya dalam sistem pemikiran Islam setelah masa al Farabi.

Metode Burhani Selanjutnya, untuk mendapatkan sebuah pengetahuan, burhani menggunakan aturan silogisme. Mengikuti Aristoteles, penarikan kesimpulan 
dengan silogisme ini harus memenuhi beberapa syarat, (1) mengetahui latar belakang dari penyusunan premis, (2) adanya konsistensi logis antara alasan dan keismpulan, (3) kesimpulan yang diambil harus bersifat pasti dan benar, sehingga tidak mungkin menimbulkan kebenaran atau kepastian lain.

\section{SIMPULAN DAN SARAN}

\section{A. Simpulan}

Berdasarkan uraian di atas, suatu kesimpulan, yaitu: 1. Pendidikan agama Islam adalah bagian dan merupakan bahan akhir dari konten yang sumbernya adalah pendidikan Islam. Sehingga dapat dikatakan bahwa pendidikan Islam adalah format dalam bentuk studi teoritis yang diterapkan melalui proses pendidikan Islam. 2. Istilah pendidikan Islam tidak dapat dipisahkan dari pendidikan Islam, sehingga perlu kesinambungan dan keselarasan antara studi teori dan aplikasi. 3. Epistemologi atau teori pengetahuan dalam hal ini pendidikan Islam memiliki relevansi dengan pendidikan agama Islam, akan mengarah pada pembinaan dan optimalisasi potensi; menanamkan nilai-nilai Islam dalam jiwa, perasaan, dan pemikiran; dan harmoni dan keseimbangan. Sehingga istilah aqidah, ibadah, dan akhlak atau dengan uraiannya dalam hal pengantar kepada Allah SWT., Potensi dan fungsi manusia serta studi moral dan diterapkan pada level aplikasi adalah pengetahuan yang cerdas, sikap dan nilai yang cerdas, dan kecerdasan dalam tindakan yang diambil dalam kehidupan sehari-hari - hari (akhlak mulia) benarbenar dapat tercermin dalam kehidupan yang saat ini masih diupayakan semaksimal mungkin oleh para pendidik dan tenaga kependidikan untuk menciptakan manusia sesuai dengan tuntutan islam.

\section{B. Saran}

Pendidikan saat ini terus berkembang seiring perkembangan zaman dengan demikian Pendidkan Agama Islam dan Pendidikan Islam sangat berperan penting untuk mengawal dan menerapaknan nilai-nilai ajaran Agama Islam agar tidak menyimpang dari ajaran yang sudah di cantumkan dalam Al-Qur'an, Hadits, ijma dan Qias dari zaman kezaman. Oleh karena itu ada 3 (tiga) poin yang harus diimpementasikan dalam Pendidikan agama Islam dan Pendidikan Islam yaitu:

1. Sebagai tenaga pengajar dan pedidik harus memberikan suritauladan sesuai dengan ajaran Islam yang menejukan. 
2. Menerapkan Pendidikan agama Islam dan Pendidikan Islam bersumber dari AlQur'an, Hadits, ijma dan Qias sebagai mana di contohkan oleh para Nabi, sahabatsahabat, tabin-tabin hingga para ulama dalam pengajaran dan mendidik,

3. Selalu berkodinasi dengan pemerintah dan masyarakat untuk menciptakan Pendidikan agama Islam dan Pendidikan Islam yang Rahmatan lilalamin.

Dari poin diatas sebagai barometer terciptanya Pendidikan agama Islam dan Pendidikan diharapkan oleh semua pihak agar generasi bangsa ini menjadi bangsa yang bermartabat dan menjunjung tinggi ilmu agama sebagai pondasi dasar.

\section{DAFTAR PUSTAKA}

A. Khudori Soleh, 2003. M. Abid Al-Jabiri Model Epistemologi Islam, dalam, A. Khudori Soleh, (edt),Pemikiran Islam Kontemporer, (Yogyakarta: Jendela)

Alim, Muhammad. 1992. Al-Tarbiyah wa al-Tanmiyah.. fi al-Islam (Riyadh: KSA)

Al-Nahlawi, Abdurrahman. 1979. Ushul al-Tarbiyah al-Islamiyah wa Asalibiha (Damaskus: Dar al-Fikr) Al-Rasyidin dan Suharto, Rudhy. tt. Ilmu dan Epistemologi, dalam Jurnal Al-Huda (Jakarta: Al-Huda)

Al-Syaibany. 1979. Falsafah al-Tarbiyyah al- Islamiyyah, Alih Bahasa: Hasan Langgulung, Falsafah Pendidikan Islam (Jakarta: Bulan Bintang)

Arifin, H. Muzayyin. 2003. Filsafat Pendidikan Islam (Jakarta: Bumi Aksara)

As, Asmaran. 2005. Karakteristik Epistemologi Islam (Ke Arah Pemahaman Dunia Sufistik),dalam Jurnal Khazanah, Volume IV, Nomor 03, Mei - Juni.

Bakhtiar, Amsal. 1994. Filsafat Ilmu (Jakarta: Rajawali Press)

D. Mulyasa. 2004. Kurikulum Berbasis Kompetensi, Konsep, Karakteristik, dan Implementasi (Bandung: PT. Remaja Rosdakarya)

H. Samsul Nizar. 1995.Filsafat Pendidikan Islam (Jakarta, Ciputat Press)

Ihsan, Hamdani dan Fuad Ihsan. 1998. FilsafatPendidikan Islam (Bandung: Pustaka Setia)

Jalaluddin dan Usman Said. 1999. Filsafat Pendidikan Islam (Jakarta: Rajawali Press)

M. Muhaimin. 2007. Pengembangan Kurikulum Pendidikan Agama Islam (Jakarta: Rajawali Press)

Muhadjir, Noeng. 1998. Filsafat Ilmu, Telaah Sistematis Fungsional Komperatif (Yogyakarta: Rake Sarasin) 
Muhammad Abid al-Jabiri, 1992. Bunyah al-'Aql al-'Arabi (Bairut: Markaz Dirasat alWihdah al-'Arabiyah)

Muhammad Abid al-Jabiri. 2000. Post Tradisionalism Islam, Terj. Ahmad Baso, (Yogyakarta: LKiS)

Nata, Abuddin. 1997. Filsafat Pendidikan Islam (Jakarta: Logos Wacana Ilmu)

Qomar, Mujamil. 2005. Epistemologi Pendidikan Islam, Dari Metode Rasional Hingga Metode Kritik (Jakarta: Erlangga)

Reynold A. Nicholson, 1987/ Tasawuf Menguak Cinta Ilahi, terj. A. Nashir Budiman (Jakarta: Rajawali)

Syahiddin. 2005. Aplikasi Metode Pendidikan Qurani dalam Pembelajaran Agama di Sekolah, (Tasikmalaya: Ponpes Suryalaya Tasikmalaya)

Tafsir, Ahmad. 1994. Ilmu Pendidikan Dalam Perspektif Islam (Bandung: PT. Remaja Rosdakarya 